\title{
Mapping of murine Th1 and Th2 helper T-cell epitopes on fimbriae from Porphyromonas gingivalis
}

\author{
T. OGAWA, H. UCHIDA and K. YASUDA
}

Department of Oral Microbiology, Osaka University Faculty of Dentistry, Yamadaoka, Suita-Osaka 565, Japan

\begin{abstract}
Summary. Th1- and Th2-derived cytokine production in response to synthetic peptides of the fimbrial subunit protein (fimbrilin) from Porphyromonas gingivalis strain 381 was assessed in spleen mononuclear cells (MNC) of BALB/c mice (H-2 ${ }^{\mathrm{d}}$ haplotype) immunised with the fimbrial protein antigen and adjuvant GM-53 in Freund's incomplete adjuvant (FIA). Sixtyseven sequential overlapping 10-mer peptides covering the complete 337 amino-acids (AA) protein of $P$. gingivalis fimbrilin were synthesised. Stimulation of spleen MNC in vitro with these 10-mer peptides resulted in the production of murine interleukin-2 (IL-2), $\gamma$-interferon (IFN- $\gamma$ ), IL-4, IL-5 and IL-6. Peptides 13 (AA 61-70), 24 (AA 116-125), 31 (AA 151-160) and 64 (AA 316-325) markedly induced IL-2 production. In particular, peptide 24 (DPLKIKRVHA), which contained I-A ${ }^{\mathrm{d}}, \mathrm{I}^{-E^{\mathrm{d}}}$ and $\mathrm{I}-\mathrm{A}^{\mathrm{k}}$ binding motifs, was the most potent stimulator of IL-2, IFN- $\gamma$, IL-4, IL-5 and IL-6 production. Spleen MNC from C3H/HeN mice $\left(\mathrm{H}-2^{\mathrm{k}}\right)$ followed by $\mathrm{BALB} / \mathrm{c}$ mice $\left(\mathrm{H}-2^{\mathrm{d}}\right)$ immunised with peptide 24 were high responders to peptide 24 in terms of both IFN- $\gamma$ and IL-4 production, whereas A/J mice $(\mathrm{H}-$ $\left.2^{\mathrm{a}}\right)$ and $\mathrm{C} 57 \mathrm{BL} / 6$ mice $\left(\mathrm{H}-2^{\mathrm{b}}\right)$ were very low responders, $P$. gingivalis fimbriae evoked higher delayed-type hypersensitivity (DTH) reactions in B10.D2 $\left(\mathrm{H}-2^{\mathrm{d}}\right)$ and B10.BR $\left(\mathrm{H}-2^{\mathrm{k}}\right)$ mice followed by C57BL/10 (B10, H-2 $\left.2^{b}\right)$ and B10.A $\left(\mathrm{H}-2^{\mathrm{a}}\right)$ and in guinea-pigs immunised with the fimbriae and GM-53 in FIA. Thus, the Th1 and Th2 helper $\mathrm{T}$ cell cytokine-producing responses and the DTH reactions to $P$. gingivalis fimbriae in mice are restricted by $\mathrm{H}-2$ haplotype and the amino-acid sequence (AA 116-125) within the fimbrial protein molecule acts as a common stimulator of cytokine production in both Th1 and Th2 cells.
\end{abstract}

\section{Introduction}

In the $\mathrm{CD}^{+}$helper $\mathrm{T}$-cell activation process, the formation of the trimolecular complex among antigenderived peptides, MHC class II (Ia) molecules and Tcell antigen receptors (TCRs) is an essential event. Furthermore, the site(s) of antigen in contact with MHC molecules (agretope) and the site(s) of antigen in contact with TCRs (epitope) play an important role in constituting the trimolecular complexes. ${ }^{1-4}$ Evidence to support this may be obtained by the responder or non-responder phenotype of $T$ cells in various strains of mice to a specific antigen. ${ }^{5,6}$ Subsequently, various lymphokines produced by activated $\mathrm{T}$ cells serve a major function in the humoral and cellular immune responses and play crucial roles in protective immunity against pathogens in infectious diseases. ${ }^{7,8}$ Murine $\mathrm{CD}^{+}$helper $\mathrm{T}$ cells have been classified into $\mathrm{Th} 1$ cells secreting interleukin-2 (IL-2), $\gamma$-interferon (IFN- $\gamma$ ) and lymphotoxin (LT)/tumor necrosis factor- $\beta$ (TNF$\beta),{ }^{9,10}$ and Th 2 cells producing IL-4, IL-5, IL-6 and IL10 in response to antigen. ${ }^{11-13}$ The Th1 cells serve as mediators of delayed-type hypersensitivity (DTH) reactions, whereas Th2 cells stimulate antibody production by B cells.

Porphyromonas gingivalis has been strongly associ-

Received 28 July 1994; revised version accepted 16 Sept. 1994. ated with the development of periodontal diseases ${ }^{14}$ and the fimbrial protein on the bacterial cell surface is thought to be important in host-parasite interaction. ${ }^{15,16} \mathrm{We}$ demonstrated that fimbriae from $P$. gingivalis strain 381 exhibited multifunctional properties such as antigenicity, mitogenicity, adjuvanticity, chemotactic activity, induction of pro-inflammatory cytokines and other factors. ${ }^{17-19}$ In immunobiological analyses with various synthetic peptides that mimicked the amino-acid sequence of the fimbrial subunit protein (fimbrilin) of $P$. gingivalis, the functional regions within the fimbrial protein molecular have been identified. ${ }^{17}$ The titre of serum fimbria-specific antibodies and the number of cells secreting antibody against $P$. gingivalis fimbriae were found to be raised in patients with periodontal diseases. ${ }^{20,21} P$. gingivalis fimbriae also possess strongly immunogenic properties and subcutaneous or oral immunisation of mice and guinea-pigs with $P$. gingivalis fimbriae and their related synthetic peptides resulted in marked humoral and cellular immune responses. ${ }^{2-24}$ Furthermore, in mice a marked genetic variation in the production of fimbriaspecific antibodies after immunisation with $P$. gingivalis fimbriae has been demonstrated ${ }^{25}$ More recently, Ogawa $^{26}$ investigated the immunodominant epitopes within the fimbrilin molecule of $P$. gingivalis by multipin peptide synthesis technology, revealing that immunisation with some synthetic peptides mimicking 
the amino-acid sequence in the immunodominant epitope regions offered protection against challenge with $P$. gingivalis.

In this study, a set of 10-mer peptides spanning the entire molecule of fimbrilin from $P$. gingivalis 381 was synthesised, then used to determine the region(s) that induced Th1- or Th2-derived cytokine production in spleen mononuclear cells of mice immunised with the fimbriae. Furthermore, the genetic control of cytokineproducing responses to synthetic peptide corresponding to $\mathrm{T}$-cell epitope in strains of mice possessing different genetic backgrounds was investigated.

\section{Materials and methods}

\section{Animals}

Four inbred mouse strains, A/J, C57BL/6, BALB/c and $\mathrm{C} 3 \mathrm{H} / \mathrm{HeN}$ mice, and four $\mathrm{H}-2$ congeneic strains, B10.A, C57BL/10 (B10), B10.D2 and B10.BR mice, were obtained from Japan SLC Co., Shizuoka, Japan. The mice were 6-week-old males. Closed-colony male albino guinea-pigs (weight $300-350 \mathrm{~g}$ ) were purchased from Nihon Rabbit Inc., Osaka, Japan.

\section{Bacteria and preparation of fimbriae from P. gingivalis 381}

$P$. gingivalis strain 381 was grown anaerobically in GAM Broth (Nissui, Tokyo, Japan) supplemented with haemin $(5 \mathrm{mg} / \mathrm{L})$ and menadione $(10 \mathrm{mg} / \mathrm{L})$ at $37^{\circ} \mathrm{C}$ for $26 \mathrm{~h}$, and the fimbriae were prepared as described previously. ${ }^{22}$ The basic structure of fimbriae (fimbrilin) was identified as a single band of the 41kDa subunit protein by SDS-PAGE. ${ }^{22}$

\section{Peptide synthesis}

In T-cell epitope mapping, 67 synthetic peptides representing the complete $P$. gingivalis fimbrilin sequence (amino acid-AA-residues 1 -337) ${ }^{27.28}$ were synthesised by a simultaneous multiple and cleavable peptide synthesis kit (Chiron Mimotopes Pty Ltd). ${ }^{29}$ Peptides were synthesised on polyethylene rods and cleaved from the rods in 96-well round-bottomed microtitration plates (Corning, New York, USA). These were then diluted in RPMI 1640 medium (Biken, Osaka, Japan) for use in the cytokine-producing assay (see below) and the peptide yield was estimated as described previously. ${ }^{26,29}$

Peptide was synthesised with a model 9050 peptide synthesiser (Japan Millipore Ltd, Tokyo) by solidphase methods. ${ }^{30}$ After cleavage of the protecting groups with trifluoroacetic acid: $m$-cresol:ethanedithiol: methanesulphonic acid $(90: 2 \cdot 5: 5: 2 \cdot 5)$, the peptide was purified by high performance liquid chromatography on a reversed phase column (Capcell Pak C18 SG120, $1.5 \times 15 \mathrm{~cm}$; Shiseido, Tokyo, Japan) with a linear gradient ( 6 to $60 \%$ ) of acetonitrile in acetic acid $0.1 \%$ at a flow rate of $23 \mathrm{ml} / \mathrm{min}$. The major peak fraction of peptide was collected by monitoring the absorbance at $220 \mathrm{~nm}$. The purified peptide was analysed for composition by quantitative amino-acid analysis and sequenced by automated Edman degradation with a protein sequencing system (Prosequencer; Japan Millipore Ltd).

\section{Adjuvants}

Sodium $\beta$ - $N$-acetylglucosaminyl-( $\rightarrow 4$ )- $N$-acetylmuramyl-L-alanyl-D-isoglutaminyl-(L)-stearoyl-(D)meso-2,6-diaminopimeric acid-(D)-amide-D-alanine (GM-53), a stearoyl derivative of the disaccharide tetrapeptide isolated from Lactobacillus plantarum cell wall, ${ }^{31}$ was generously supplied by Dainippon Pharmaceutical Co., Osaka, Japan, and Freund's incomplete adjuvant (FIA) was purchased from Difco.

\section{Cytokine production}

On days 0 and 14 , the fimbriae $(100 \mu \mathrm{g})$ or the synthetic peptide segment $(100 \mu \mathrm{g})$ with adjuvant GM$53(100 \mu \mathrm{g})$ in FIA $(0.2 \mathrm{ml} /$ mouse $)$ were administered subcutaneously to groups of five mice. Spleens were removed on day 28 , and the cells were isolated and fractionated with Histopaque (Sigma) to obtain mononuclear cells (MNC).$^{32}$ MNC were washed and suspended at a cell density of $8 \times 10^{6}$ cells $/ \mathrm{ml}$ of RPMI 1640 medium (Biken) supplemented with fetal bovine serum (FBS; HyClone, Logan, UT, USA) $10 \%$. Test specimens $(10 \mu \mathrm{g} / 100 \mu \mathrm{l})$ were then added to MNC $\left(8 \times 10^{5}\right.$ cells $\left./ 100 \mu \mathrm{l}\right)$, and the cells were incubated at $37^{\circ} \mathrm{C}$ for $24 \mathrm{~h}$ (for IL-2 assay) or for $72 \mathrm{~h}$ (for assays of IFN- $\gamma$, IL-4, IL-5 and IL-6) in a 96-well microtitration plate (Falcon 3072; Becton Dickinson and Co., Lincoln Park, NJ, USA), respectively. ${ }^{33}$ After incubation, culture supernates were collected and cytokines were quantified by ELISA-IL-2, IL-4, IL-5 and IL-6 (Endogen Inc. Boston, MA, USA) and IFN- $\gamma$ (Genzyme, Cambridge, MA, USA). These assays were performed according to the manufacturers' instructions, and the data were interpreted from a standard curve prepared for each assay.

\section{Assay for delayed-type hypersensitivity (DTH) reactions in guinea-pigs and different strains of mice}

Groups of six guinea-pigs were immunised with $100 \mu \mathrm{g}$ of fimbriae or peptide 24 (AA 116-125) with $100 \mu \mathrm{g}$ of adjuvant GM-53 in FIA on day 0 . Skin tests were performed to evaluate the T-cell response specific for $P$. gingivalis fimbriae in vivo. ${ }^{24}$ Briefly, the guineapigs were inoculated intracutaneously with $100 \mu \mathrm{g}$ of fimbriae or synthetic peptide 35 days after immunisation. The skin was examined for evidence of erythema (longest length $[\mathrm{mm}] \times$ shortest length $[\mathrm{mm}]$ ) $48 \mathrm{~h}$ later. Groups of six mice were also immunised by subcutaneous injection of $100 \mu \mathrm{g}$ of fimbriae or synthetic peptide with $100 \mu \mathrm{g}$ of GM-53 in FIA on days 0 and 14. The immunised mice were given either an injection of $100 \mu \mathrm{g}$ of fimbriae or synthetic peptide into the right hind footpad 2 weeks later (day 28). Footpad swelling (thickness, $\mathrm{mm}$ ) at the injection site was measured $48 \mathrm{~h}$ after the provocative injection and the stimulation index for footpad swelling was calculated 


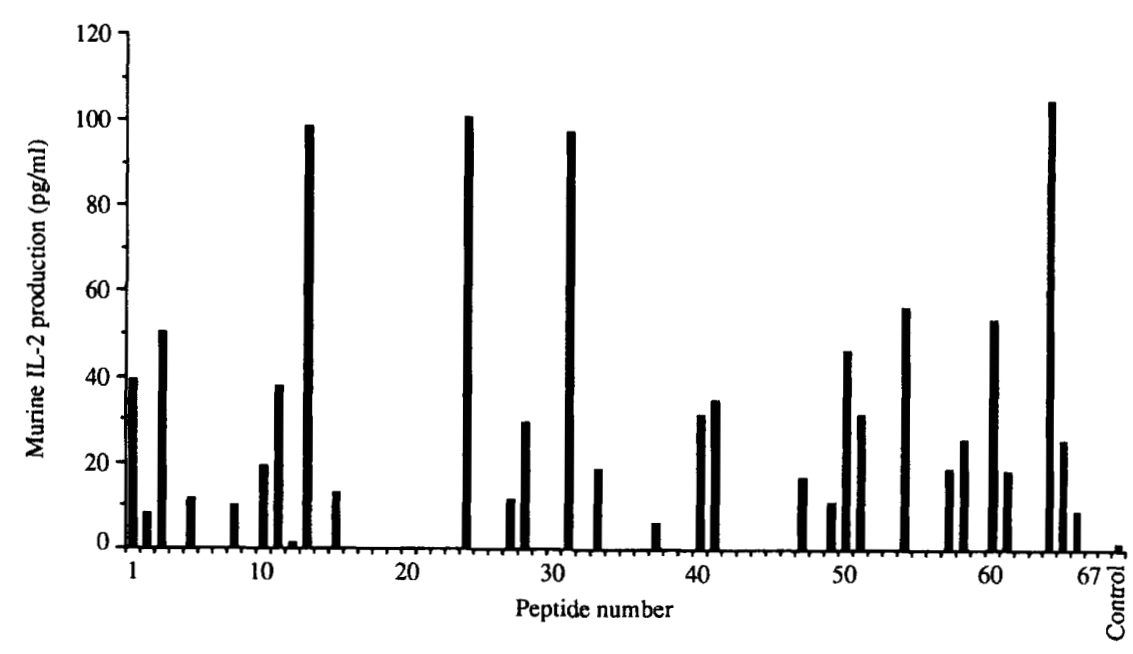

Fig. 1. IL-2 production in 24-h spleen MNC cultures from $P$. gingivalis fimbriae-immunised BALB/c mice stimulated with one of the 67 synthetic peptides of the fimbrilin $(10 \mu \mathrm{g} / \mathrm{ml})$ or in non-stimulated culture (control). The experiments were performed two or three times and only representative data are indicated. Values are expressed as cytokine production $(\mathrm{pg} / \mathrm{ml})$ and the standard error was $<10 \%$ in any experiment.

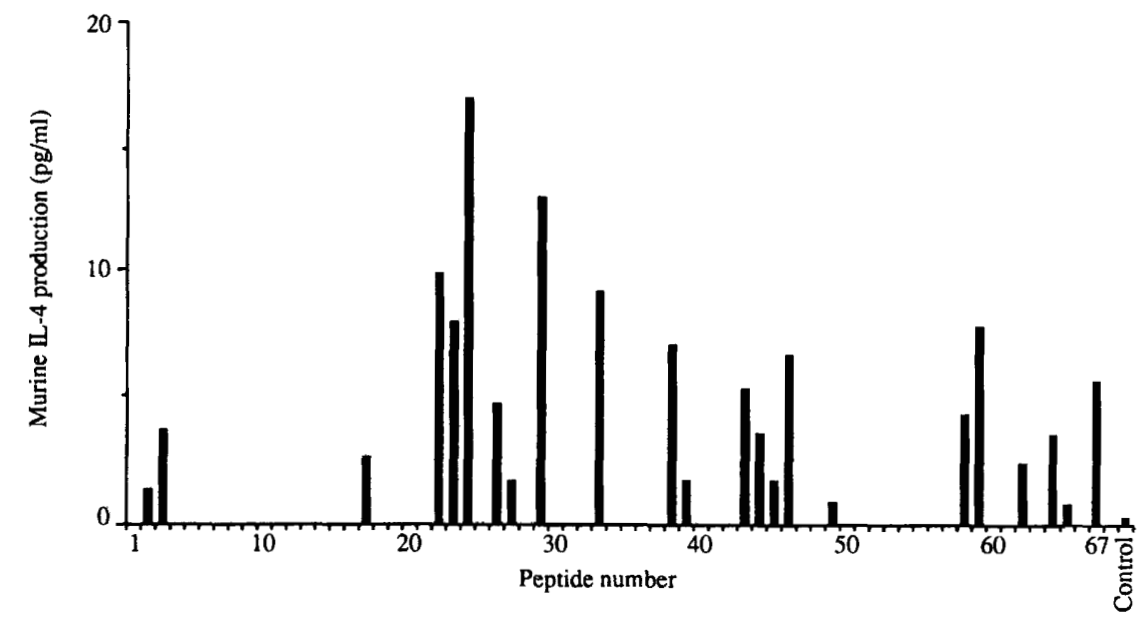

Fig. 2. IL-4 production in 72-h spleen MNC cultures from $P$. gingivalis fimbriae-immunised BALB/c mice stimulated with one of the 67 synthetic peptides of the fimbrilin $(10 \mu \mathrm{g} / \mathrm{ml})$ or in non-stimulated culture (control). The experiments were performed two or three times and only representative data are indicated. Values are expressed as cytokine production $(\mathrm{pg} / \mathrm{ml})$ and the standard error was $<10 \%$ in any experiment.

as follows: stimulation index = footpad swelling (thickness, $\mathrm{mm}$ ) in test group/footpad swelling ( $\mathrm{mm}$ ) in control (GM-53 in FIA) group.

\section{Computer predictions of antigenic determinants}

T-cell epitopes within the fimbrial protein molecule of $P$. gingivalis were predicted according to the TSites program. ${ }^{34}$

\section{Statistical analysis}

The significant difference between the mean results for the different groups was determined by the Student's $t$ test.

\section{Results}

Cytokine production in response to synthetic peptides from P. gingivalis fimbriae in spleen MNC cultures from fimbriae-immunised $B A L B / c$ mice

IL-2 was produced in substantial concentrations after stimulation with peptides 13 (AA 61-70), 24 (AA 116-125), 31 (AA 151-160) and 64 (AA 316-325) in BALB/c mice $\left(\mathrm{H}-2^{\mathrm{d}}\right)$ immunised with $P$. gingivalis fimbriae (fig. 1). Three of these peptides contained the I- $A^{\mathrm{d}}$ binding motif of $P$. gingivalis fimbrilin, the exception being peptide 64 . The highest reactivity for IFN- $\gamma$ production was found in response to peptide 24 (AA 116-125) (data not shown). Peptide 24 contains both the I-E $E^{d}$ and I-A ${ }^{\mathrm{d}}$ binding motifs but not the Rothbard and Taylor motif according to the TSites program. ${ }^{26,34}$ Peptides 22 (AA 106-115), 23 (AA 111-120), 24 (AA 116-125), 29 (AA 141-150) and 33 (AA 161-170) induced high IL-4 production (fig. 2). Peptide 24 also induced the most IL-5 production (data not shown). IL-6 was produced after stimulation with 18 peptides but values of $>60 \mathrm{pg} / \mathrm{ml}$ were recorded for peptides 1 (AA 1-10), 13 (AA 61-70), 21 (AA 101-110), 24 (AA 116-125), 31 (AA 151-160), 41 (AA 201-210), 52 (AA 256-265), 64 (AA 316-325) and 65 (AA 321-330) (fig. 3). Overall, peptide 24 was found to stimulate the release of maximal concentrations of the five cytokines tested. 


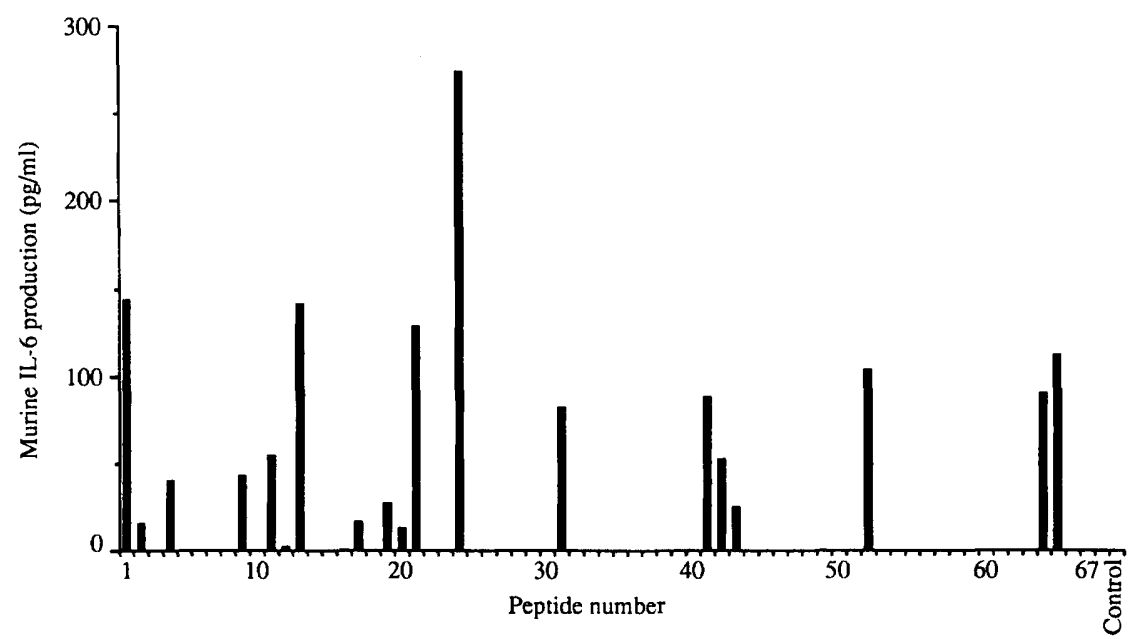

Fig. 3. IL-6 production in 72-h spleen MNC cultures from $P$. gingivalis fimbriae-immunised BALB/c mice stimulated with one of the 67 synthetic peptides of the fimbrilin $(10 \mu \mathrm{g} / \mathrm{ml})$ or in non-stimulated culture (control). The experiments were performed two or three times and only representative data are indicated. Values are expressed as cytokine production $(\mathrm{pg} / \mathrm{ml})$ and the standard error was $<10 \%$ in any experiment.

Cytokine production in response to peptide 24 ( $A A$ 116-125) in spleen $M N C$ cultures from mouse strains previously immunised with peptide 24

The responses of four strains of mice in terms of IFN- $\gamma$ and IL- 4 production to peptide 24 are presented in fig. 4. The $\mathrm{H}-2$ haplotype corresponded to the magnitude of the response, with $\mathrm{C} 3 \mathrm{H} / \mathrm{HeN}$ mice $\left(\mathrm{H}-2^{\mathrm{k}}\right)$ followed by $\mathrm{BALB} / \mathrm{c}$ mice $\left(\mathrm{H}-2^{\mathrm{d}}\right)$ producing a very strong reaction, whereas $A / J$ mice $\left(H-2^{a}\right)$ and C57BL/6 mice (H-2 ${ }^{\text {b }}$ barely responded (fig. 4).

\section{DTH reactions in guinea-pigs and mouse strains} immunised with $P$. gingivalis fimbriae or peptide 24

The intradermal challenge of guinea-pigs previously immunised with fimbriae from $P$. gingivalis with whole fimbriae elicited a DTH reaction, but no response was produced to peptide 24 (data not shown). $P$. gingivalis fimbriae and peptide 24 were also investigated for induction of DTH reactions in various mouse strains. $P$. gingivalis fimbriae evoked a greater footpad reaction in B10.D2 $\left(\mathrm{H}-2^{\mathrm{d}}\right)$ and B10.BR $\left(\mathrm{H}-2^{\mathrm{k}}\right)$ mice than in C57BL/10 (B10, H-2 $\left.{ }^{\mathrm{b}}\right)$ and B10.A $\left(\mathrm{H}-2^{\mathrm{a}}\right)$ mice previously immunised with fimbriae and GM-53 in FIA. However, peptide 24 scarcely elicited a footpad re-

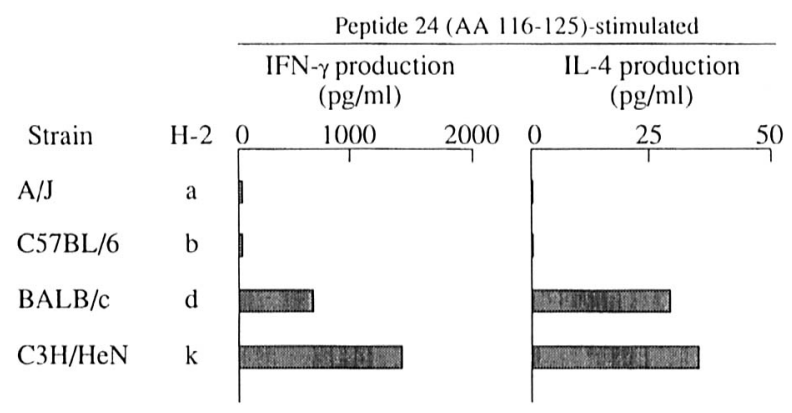

Fig. 4. IFN- $\gamma$ and IL-4 production by 72-h spleen MNC cultures induced by peptide 24 in four different strains of mice previously immunised with the same peptide $(10 \mu \mathrm{g} / \mathrm{ml})$. The experiments were performed on two or three occasions and only representative data are indicated. Values are expressed as cytokine production $(\mathrm{pg} / \mathrm{ml})$ and the standard error was $<10 \%$ in any experiment. action in any of the mice immunised with either $P$. gingivalis fimbriae or peptide 24 (fig. 5).

\section{Discussion}

Potent regions for inducing Th1-derived cytokines (IL-2, IFN- $\gamma$ ) and Th2-derived cytokines (IL-4, IL-5 and IL-6) within the fimbrial protein molecule from $P$. gingivalis were defined by priming BALB/c mice $(\mathrm{H}$ $2^{\mathrm{d}}$ ) with the fimbriae. Some Th1 and Th2 helper T-cell epitopes were found in terms of IL-2, IL-4 and IL-6 production (figs. 1-3) and only one region, corresponding to AA residues at positions 116-125, elicited IFN- $\gamma$ and IL-5 production. The number of helper Tcell epitope(s) within a protein antigen molecule and the type of cytokine produced may be associated with a good control of the immune response through the helper T-cell function. Among these epitope regions, peptide 24 that corresponded to AA 116-125 of $P$. gingivalis fimbrilin was found to elicit powerful Th1- and Th2-derived cytokine production. Analysis of the amino-acid sequence at positions 116-125 (DPLKIKRVHA) for possible T-cell epitopes with the TSites program ${ }^{34}$ revealed that peptide 24 (AA 116-

Table. Sequence comparison of deduced amino acids between 120 and 125 in the fimbrilin from various strains of $P$. gingivalis

\begin{tabular}{lcccccc}
\hline P. gingivalis strain no. & \multicolumn{7}{c}{ Amino-acid sequence* } \\
\hline & 120 & & & & & 125 \\
381 & I & K & R & V & H & A \\
ATCC33277 & I & K & R & V & H & A \\
BH18/10 & I & K & R & V & H & A \\
HW24D1 & I & K & R & V & H & A \\
OMZ314 & I & K & R & V & H & A \\
OMZ409 & I & K & R & V & H & A \\
6/26 & I & K & R & V & H & A \\
ATCC49417 & I & K & R & V & R & A \\
HG564 & V & T & R & V & H & A
\end{tabular}

* Fujiwara et al. ${ }^{35}$ 


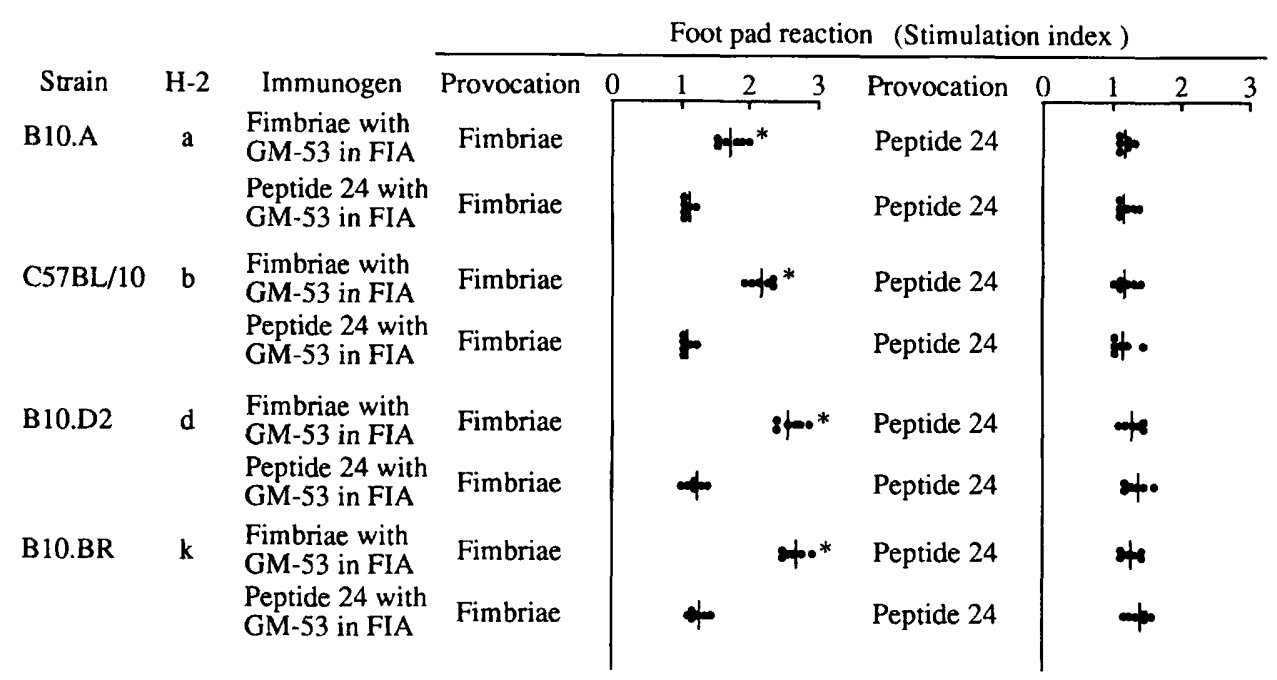

Fig. 5. Delayed-type hypersensitivity reactions to $P$. gingivalis fimbriae or peptide 24 in four congeneic strains of mice. Mice were immunised with $100 \mu \mathrm{g}$ of fimbriae or peptide 24 with $100 \mu \mathrm{g}$ of adjuvant GM-53 in FIA or with GM-53 in FIA alone. The footpad stimulation index was measured $48 \mathrm{~h}$ after inoculation. The stimulation index in the control group was $1.00 \pm 0.02(\mathrm{~B} 10 . \mathrm{A}$ and $\mathrm{B} 10 . \mathrm{BR}$ mice) and $1.00 \pm 0.03$ (C57BL/10 and B10.D2 mice). The individual values are expressed as points and the bar indicates the median value. ${ }^{*}$ Significant difference compared to the control group, $\mathrm{p}<0.01$.

125) did indeed show the predicted site. Both $\mathrm{I}-\mathrm{A}^{\mathrm{d}}$ and I- $E^{d}$ binding motifs were found at positions $120-125$ and $121-125$ and further amphipathicity was present at positions 119 and 120 . All strains of $P$. gingivalis tested $^{35}$ shared the same or similar AA sequence at positions 120-125 (IKRVHA) for fimbrilin as strain 381 (table). Furthermore, the AA sequence at positions 120-125 (VTRVHA) of $P$. gingivalis HG564 fimbrilin, which was considerably different from the sequence in the other strains, almost completely coincided with the $\mathrm{I}-\mathrm{A}^{\mathrm{d}}$ binding motif predicted by Sette et al.$^{36}$. They demonstrated that the residue at the first position appeared to be commonly occupied by $\mathrm{V}, \mathrm{I}$ or $\mathrm{L}$ in the I- $A^{\mathrm{d}}$-restricted immunogenic peptides, and the second position was occupied by $H, R, K$ or T, and position 6 was occupied by A, S or G. Thus, all strains of $P$. gingivalis tested share a common structural $\mathrm{I}-\mathrm{A}^{\mathrm{d}}$ binding motif (table). Furthermore, the residue at position 1,2 or 3 is basic, namely $\mathrm{R}, \mathrm{H}$ or $\mathrm{K}$, as are the residues at positions 4 and 6 ; the residue at position 5 is non-charged and hydrophobic in the $\mathrm{I}^{\mathrm{a}} \mathrm{E}^{\mathrm{d}}$ binding motif. Finally the AA sequence at positions $120-125$ in all the strains of $P$. gingivalis tested contained $\mathrm{I}-\mathrm{E}^{\mathrm{d}}$ binding motif. ${ }^{36}$ These findings seem to indicate that $T$ cells could widely recognise variable AA sequences of protein associated with pathogenicity in the I- $\mathrm{A}^{\mathrm{d}}$ binding system, even when patients with periodontal diseases are infected with variants of $P$. gingivalis.

It was shown previously that $\mathrm{BALB} / \mathrm{c}$ and $\mathrm{DBA} / 2$ mice $\left(\mathrm{H}-2^{\mathrm{d}}\right)$ were high responders; $\mathrm{CBA} / \mathrm{J}$ and $\mathrm{C} 3 \mathrm{H}$ mice $\left(\mathrm{H}-2^{\mathrm{k}}\right)$ were intermediate, and $\mathrm{C} 57 \mathrm{BL} / 6$ mice $(\mathrm{H}-$ $2^{b}$ ) were low responders to $P$. gingivalis fimbriae in terms of serum IgG and salivary IgA. ${ }^{25}$ Furthermore, in $\mathrm{H}-2$ recombinants on a $\mathrm{B} 10$ background, highB10.D2 (H-2 $)$ followed by B10.BR $\left(\mathrm{H}-2^{\mathrm{k}}\right)$-and low-C57BL/10 (B10, H-2 $\left.{ }^{\mathrm{b}}\right)$-responders to the fimbrial antigen were identified. These results indicate strongly that the antibody responses to the fimbrial antigen were restricted by the H-2 haplotype. In this study, peptide 24 (AA 116-125) induced strong Th1/ Th2 cytokine production in spleen MNC cultures of $\mathrm{C} 3 \mathrm{H} / \mathrm{HeN}$ mice $\left(\mathrm{H}-2^{\mathrm{k}}\right)$ followed by BALB $/ \mathrm{c}$ mice $(\mathrm{H}-$ $2^{\mathrm{d}}$ ) immunised with peptide 24 (fig. 4). Peptide 24 (DPLKIKRVHA) contains I-A ${ }^{\mathrm{d}}$ and $\mathrm{I}^{-\mathrm{E}^{\mathrm{d}}}$ binding motifs as described above ${ }^{36}$ as well as the $\mathrm{I}-\mathrm{A}^{\mathrm{k}}$ binding motif reported by Itoh et al. ${ }^{37}$ The latter demonstrated that AA residues 46 and 54 on a synthetic peptide composed of $\mathrm{D}$ at position 46 and $\mathrm{A}$ at position 54 of pigeon cytochrome $c$, function as agretopes in $\mathrm{I}-\mathrm{A}^{\mathrm{k}}$ carrying mice. Residues among AA 116-125 of $P$. gingivalis fimbrilin were found to be $\mathrm{D}$ at position 116 and $\mathrm{A}$ at position 125. B10.D2 (H-2 $\left.{ }^{\mathrm{d}}\right)$ and B10.BR $\left(\mathrm{H}-2^{\mathrm{k}}\right)$ mice also showed high responses to the fimbriae in the DTH reactions (fig. 5). Thus, these responses to $P$. gingivalis fimbriae in mice were associated with $\mathrm{H}-2$ haplotype. However, peptide 24 (AA 116-125) scarcely elicited a DTH reaction in either guinea pigs or mice (fig. 5). We demonstrated previously that synthetic peptide FP381 (202-221), which corresponds to amino-acid residue numbers $202-221$ based on the AA sequence of fimbrilin from $P$. gingivalis strain 381, elicited humoral and cellular immune responses in guinea-pigs immunised with the fimbriae or FP381 (202-221), ${ }^{24}$ and FP381 (202-221) contained the regions responsible for the immunodominant epitopes of $P$. gingivalis fimbrial molecules. ${ }^{26}$ It appears that the region corresponding to AA 116-125 of $P$. gingivalis fimbrilin may play an important role in the development of DTH reactions as well as in the antibody production by $\mathrm{B}$ cells, and the T-cell immune response to the region is restricted by both $\mathrm{H}-2^{\mathrm{d}}$ and $\mathrm{H}-2^{\mathrm{k}}$ haplotypes.

Taken together, among Th1- or Th2-derived cytokine-inducing region(s) the most potent AA sequence at positions 116-125 within the $P$. gingivalis fimbrilin molecule was identified in the mice previously immunised with the fimbrial antigen. The distinct IgG response against peptide 24 (AA 116-125) found in 
serum specimens from the patients with adult periodontitis ${ }^{26}$ and peptide vaccination studies have provided a well-defined approach for vaccination against infection with $P$. gingivalis. ${ }^{22,26}$ Vaccination studies

\section{References}

1. Watts TH, Gaub HE, McConnell HM. T-cell-mediated association of peptide antigen and major histocompatibility complex protein detected by energy transfer in an evanescent wave-field. Nature 1986; 320: 179-181.

2. Schwartz RH. Immune response (Ir) genes of the murine major histocompatibility complex. Adv Immunol 1986; 38: 31201.

3. Allen PM, Matsueda GR, Evans RJ, Dunbar JB, Marshall GR, Unanue ER. Identification of the T-cell and Ia contact residues of a T-cell antigenic epitope. Nature 1987; 327: $713-715$.

4. Sette A, Buus S, Colon S, Smith JA, Miles C, Grey HM Structure characteristics of an antigen required for it interaction with Ia and recognition by T cells. Nature 1987 328: 395-399.

5. Babbitt DP, Allen PM, Matsueda G, Haber E, Unanue ER. Binding of immunogenic peptides to Ia histocompatibility molecules. Nature $1985 ; 317$ : 359-361.

6. Buus S, Sette A, Colon SM, Miles C, Grey HM. The relation between major histocompatibility complex (MHC) restriction and the capacity of Ia to bind immunogenic peptides Science 1987 ; 235: 1353-1358.

7. Yamamura M, Uyemura K, Deans RJ et al. Defining protective responses to pathogens: cytokine profiles in leprosy lesions. Science 1991; 254: 277-279.

8. Haanen JBAG, de Waal Malefijt R, Res PCM et al. Selection of a human $\mathrm{T}$ helper type 1-like $\mathrm{T}$ cell subset by mycobacteria. $J$ Exp Med 1991; 174: 583-592.

9. Cher DJ, Mosmann TR. Two types of murine helper T cell clone. II. Delayed-type hypersensitivity is mediated by $\mathrm{Th}$ 1 clones. J Immunol 1987; 138: 3688--3694.

10. Stout RD, Bottomly K. Antigen-specific activation of effector macrophages by IFN- $\gamma$-producing (Th1) $\mathrm{T}$ cell clones. Failure of IL-4 producing (Th2) T cell clones to activate effector function in macrophages. $J$ Immunol 1989; 142: 760-765.

11. Killar L, MacDonald G, West J, Woods A, Bottomly K. Cloned, Ia-restricted $\mathrm{T}$ cells that do not produce interleukin 4 (IL4)/B cell stimulator factor 1 (BSF-1) fail to help antigen-specific B cells. $J$ Immunol $1987 ; 138$ : 1674-1679.

12. Coffman RL, Seymour BW, Lebman DA et al. The role of helper $\mathrm{T}$ cell products in mouse $\mathrm{B}$ cell differentiation and isotype regulation. Immunol Rev 1988; 102: 5-28.

13. Boom WH, Liano D, Abbas AK. Heterogeneity of helper/ inducer $\mathrm{T}$ lymphocytes. II Effects of interleukin 4- and interleukin 2-producing $\mathrm{T}$ cell clones on resting $\mathrm{B}$ lymphocytes. J Exp Med 1988; 167: 1350-1363.

14. Slots J, Genco RJ. Black-pigmented Bacteroides species, Capnocytophaga species, and Actinobacillus actinomycetemcomitans in human periodontal disease: virulence factors in colonization, survival, and tissue destruction. $J$ Dent Res $1984 ; 63: 412-421$.

15. Slots J, Gibbons RJ. Attachment of Bacteroides melaninogenicus subsp. asaccharolyticus to oral surfaces and its possible role in colonization of the mouth and of periodontal pockets. Infect Immun 1978; 19: 254-264.

16. Okuda K, Slots J, Genco RJ. Bacteroides gingivalis, Bacteroides asaccharolyticus and Bacteroides melaninogenicus subspecies: cell surface morphology and adherence to erythrocytes and human buccal epithelial cells. Curr Microbiol $1981 ; 6: 7-12$.

17. Ogawa T, Kusumoto $Y$, Uchida $H$, Nagashima S, Ogo H, Hamada S. Immunobiological activities of synthetic peptide segments of fimbrial protein from Porphyromonas gingivalis. Biochem Biophys Res Commun 1991; 180: 1335-1341.

18. Ogawa $\mathrm{T}$, Ogo H, Hamada $\mathrm{S}$. Chemotaxis of human monocytes by synthetic peptides that mimic segments of Porphyromonas gingivalis fimbrial protein. Oral Microbiol Immun 1994; 9: 257-261. with chemically defined peptides recognised by the $T$ helper subset(s) in contact with antigen-presenting cells should assist in the development of a more effective peptide vaccine and further studies are in progress.

19. Ogawa T, Uchida H, Hamada S. Porphyromonas gingivalis fimbriae and their synthetic peptides induce proinflammatory cytokines in human peripheral blood monocyte cultures. FEMS Microbiol Lett 1994; 116: 237-242.

20. Ogawa T, Kusumoto Y, Hamada S, McGhee JR, Kiyono H. Bacteroides gingivalis-specific serum IgG and IgA subclass antibodies in periodontal diseases. Clin Exp Immunol 1990; 82: $318-325$.

21. Ogawa T, Kono Y, McGhee ML et al. Porphyromonas gingivalis-specific serum IgG and IgA antibodies originate from immunoglobulin-secreting cells in inflamed gingiva. Clin Exp Immunol 1991; 83: 237-244.

22. Ogawa T, Shimauchi H, Hamada S. Mucosal and systemic immune responses in BALB/c mice to Bacteroides gingivalis fimbriae administered orally. Infect Immun 1989; 57: 3466-3471.

23. Ogawa T, Kusumoto Y, Kiyono H, McGhee JR, Hamada S. Occurrence of antigen-specific B cells following oral or parenteral immunization with Porphyromonas gingivalis fimbriae. Int Immunol 1992; 4 : 1003-1010.

24. Ogawa T, Ogo H, Uchida H, Hamada S. Humoral and cellular immune responses to the fimbriae of Porphyromonas gingivalis and their synthetic peptides. $J$ Med Microbiol $1994 ; 40: 397-402$.

25. Shimauchi $\mathrm{H}$, Ogawa $\mathrm{T}$, Hamada $\mathrm{S}$. Immune response gene regulation of the humoral immune response to Porphyromonas gingivalis fimbriae in mice. Immunology 1991; 74: 362-364

26. Ogawa $T$. The potential protective immune responses to synthetic peptides containing conserved epitopes of Porphyromonas gingivalis fimbrial protein. J Med Microbiol 1994; 41 : 349-358

27. Geysen HM, Meloen RH, Barteling SJ. Use of peptide synthesis to probe viral antigens for epitopes to a single amino acid. Proc Natl Acad Sci USA 1984; 81 : 3998-4002.

28. Dickinson DP, Kubiniec MA, Yoshimura F, Genco RJ. Molecular cloning and sequencing of the gene encoding the fimbrial subunit protein of Bacteroides gingivalis. $J$ Bacteriol 1988 ; 170 : 1658-1665.

29. Maeji NJ, Bray AM, Geysen HM. Multi-pin peptide synthesis strategy for T cell determinant analysis. J Immunol Methods 1990; 134: 23-33.

30. Merrifield RB. Solid phase peptide synthesis. I. The synthesis of a tetrapeptide. J Am Chem Soc 1963; 85: 2149-2154.

31. Furuta R, Kawata S, Naruto S, Minami A, Kotani S. Synthesis and biological activities of $N$-acetylglucosaminyl- $\beta-(1 \rightarrow$ 4)- $N$-acetylmuramyl tri- and tetra-peptide derivatives. Agric Biol Chem 1986; 50: 2561-2572.

32. Böyum A. Isolation of mononuclear cells and granulocytes from human blood. Isolation of mononuclear cells by one centrifugation, and of granulocytes by combining centrifugation and sedimentation at $1 \mathrm{~g}$. Scand J Clin Lab Invest 1968; 21 Suppl 97: 77-89.

33. Huygen K, Lozes E, Gilles B et al. Mapping of TH1 helper Tcell epitopes on major secreted Mycobacterial antigen $85 \mathrm{~A}$ in mice infected with live Mycobacterium bovis BCG. Infect Immun 1994; 62: 363-370.

34. Feller DC, de La Cruz VF. Identifying antigenic T-cell sites. Nature 1991 ; 349: 720-721.

35. Fujiwara T, Morishima S, Takahashi I, Hamada S. Molecular cloning and sequencing of the fimbrilin gene of Porphyromonas gingivalis strains and characterization of recombinant proteins. Biochem Biophys Res Commun 1993; 197: 241-247.

36. Sette A, Buus S, Appella $\mathrm{E}$ et al. Predication of major histocompatibility complex binding regions of protein antigens by sequence pattern analysis. Proc Natl Acad Sci USA $1989 ; 86: 3296-3300$.

37. Itoh Y, Ogasawara K, Takami K et al. Determination of amino acids on agretopes of pigeon cytochrome $c$-related peptides specifically bound to I-A allelic products. Eur J Immunol $1994 ; 24: 76-83$ 